The "Blue Jay" is certainly a grand magazine and the items are always of great interest. I look forward to every issue. I do wish that I could write well enough to make a contribution sometimes but have no talent for expressing items on paper. (That is just pure imagination! Let us hear from you next time.-Ed.) My effort lies in keeping food for the birds ready at all times and "preaching" bird conservation to every visitor.

ANNE OLSON, Big River, Sask.

\section{A Farmer Looks at Wildlife}

Mrs. Elizabeth Hubbard of Grenfell, Saskatchewan, has sent us a most interesting article on wildlife conservation, reprinted from "The Agricultural Institute Review," and now published in pamphlet form by The Canadian Wheat Pools. The story was written by E. S. Russenholt, of The Canadian Cooperative Wheat Producers, Ltd., Winnipeg, who has written as an introduction:

"Last fall I visited my own homestead in the Swan River Valley where the Northland meets the Prairies - in Manitoba. The change since I left it in 1914, is almost beyond belief.

"Then the hills, south and west, were heavy with timber, and alive with logging camps. The lowlands were solid bush, broken by long muskegs. Water, knee-deep on the level, delayed haying until August. Clearings, hacked out by axe, fire and ox-power, grew fine gardens and feed grains for home use. Sawmills shipped out trainloads of lumber.

"Now the hills are bare of timber. Logging camps are memories. Rivers flood in spring and wither in summer. Muskegs are dry. Open fields stretch mile on mile. Sawmills are replaced by grain elevators that yearly handle millions of bushels."

Do you wish to learn of the dire mistakes that have been made during this remarkable change? Do you believe that wildlife destruction is an inevitable part of "development"?
What should we do about wildlife in developing the best use of our lands and waters? Do you believe that Conservation is: "The use of all our resources of land and water - for the greatest good of the greatest number of all our people"?

If so, write for a copy of this pamphlet to the Canadian Cooperative Wheat Producers, Ltd., Winnipeg. Every advocate of Conservation should get a copy of "A Farmer Looks at Wildlife."

\section{SUMMER TREASURE \\ (Continued from Page 1)}

But to crown summer's experience we spent an afternoon with some of earth's bright company, a group of Avocets. A hot day, brilliant sunshine, breeze off the water and these dazzling creatures. Their long claretpink necks, vivid blue long legs, black and white wings and white bodies, casually swimming, flying, standing and walking so near to us was too thrilling for words. Arrowheads in waxy white bloom set a scene of beauty. Willets, godwits and sandpipers kept them company in the shallow slough. Song sparrows, kingbirds, redwings and martins quenched their thirst beside us, but all seemed incidental in this tryst with beauty.

"What riches has eternity that it can give away -

Such infinite perfection to just a passing day?"

A highlight for a day? A year? A life time!

We did not travel this summer, we had no need to. Treasure was all about us.

Beside us a floral ladder climbed the poplar trunk, the topmost leaves joining to form a cup for the honey suckle spikes of orange and pink. The nectar in the long slender tubes must be reserved for humming birds only.

In the pasture shooting stars fringed the pool where the cattle slaked their thirst. How well named these little cyclamen relatives are, flame coloured anthers and magenta petals. Was it the moist surroundings that gave the blossoms their spicy cinnamon odour? 